\title{
Cardiovascular changes after administration of aerosolized salbutamol in horses: five cases
}

\author{
Daniela Casoni ${ }^{*}{ }^{*}$, Claudia Spadavecchia and Chiara Adami ${ }^{\dagger}$
}

\begin{abstract}
Prevention and treatment of intraoperative hypoxemia in horses is difficult and both efficacy and safety of therapeutic maneuvers have to be taken into account. Inhaled salbutamol has been suggested as treatment of hypoxia in horses during general anesthesia, due to safety and ease of the technique. The present report describes the occurrence of clinically relevant unwanted cardiovascular effects (i.e. tachycardia and blood pressure modifications) in 5 horses undergoing general anesthesia in dorsal recumbency after salbutamol inhalation. Balanced anesthesia based on inhalation of isoflurane in oxygen or oxygen and air and continuous rate infusion (CRI) of lidocaine, romifidine, or combination of lidocaine and guaifenesine and ketamine was provided. Supportive measures were necessary to restore normal cardiovascular function in all horses but no long-term adverse effects were noticed in any of the cases.
\end{abstract}

Keywords: Salbutamol, Horse, Anesthesia, Cardiovascular side effects

\section{Background}

Despite delivery of high-inspired oxygen concentration, suboptimal arterial partial pressure of oxygen $\left(\mathrm{PaO}_{2}\right)$ and hypoxemia are frequently observed in horses undergoing general anesthesia [1-4]. In this context, hypoxemia, defined as a $\mathrm{PaO}_{2}$ lower than $60 \mathrm{~mm} \mathrm{Hg}$ is secondary to considerable changes in ventilation and blood flow distribution in the equine lung, among which the most important is the development of a large intrapulmonary right-to-left vascular shunting [3,5]. Dorsal recumbency is positively correlated with the incidence of hypoxaemia. Preventing or treating intraoperative hypoxaemia has proved difficult and no ideal technique is currently available in the clinical practice. In light of its supposed efficacy in improving gas exchange efficiency, clenbuterol, a $\beta$-adrenergic agonist, was administered intravenously with inconsistent [6,7] effects. However, the administration of salbutamol aerosol in intubated horses with low $\mathrm{PaO}_{2}$ has been previously demonstrated effective [1]. Salbutamol is a non-catecholamine $\beta$-adrenergic agonist with prevalent selectivity for $\beta_{2}$ receptors, used in human patients affected by asthma and in horses with

\footnotetext{
* Correspondence: daniela.casoni@vetsuisse.unibe.ch

${ }^{\dagger}$ Equal contributors

Anaesthesiology and Pain Therapy Division, Department of Clinical Veterinary Sciences of the Vetsuisse Faculty of Berne, Länggassstrasse 124, CH-3012
} Berne, Switzerland

recurrent airways diseases. Although it is well known that there is a large inter individual variation in response to $\beta$-adrenoreceptor ligands in vivo, the $\beta_{2}$-selectivity in vitro is characterized by a higher intrinsic activity and higher affinity at $\beta_{2}$ than at $\beta_{1}$-adrenoreptors [8].

The mechanism of its beneficial action on improving $\mathrm{PaO}_{2}$ under anesthesia is still unclear. It has been suggested that the improvement of ventilation/perfusion (V/Q) mismatches is mediated by the opening of small airways in perfused lung regions, thereby allowing uptake of oxygen by blood in those areas [1]. Improvement of peripheral airflow obstruction has also been postulated in patients affected by primary pulmonary hypertension [9]; instead, no improvement of pulmonary oxygenation secondary to bronchodilator effect has been reported in clinically healthy horses [10]. The technique has the main advantage of being easy to learn, straightforward, non-invasive and safe. In case of systemic absorption, salbutamol effects on $\beta_{1}$ and $\beta_{2}$ receptors located extrabronchially, could lead to positive inotropy and chronotropy secondary to cardiac stimulation and peripheral muscular vasodilation. However, no tachycardia was observed in horses following salbutamol administration in clinical settings [1]. In experimental healthy horses in dorsal recumbency, a positive chronotropic effect without clinical relevance was temporarily recorded [11]. This case series reports the occurrence of 
clinically relevant cardiovascular effects i.e. tachycardia in 4 cases, and ventricular arrhythmia associated with systemic arterial hypotension in 1 case following the inhalation of salbutamol aerosol in anaesthetized horses in dorsal recumbency.

\section{Case presentations}

\section{Anesthesia protocol and monitoring}

Details relative to the anesthesia protocols for each patient are summarized in Table 1. After endotracheal intubation, inhalational anesthesia was maintained with isoflurane in oxygen or in oxygen and air (Table 1) through a circle system designed for large animal and connected to an adjustable time cycled ventilator (DHV 1000 Large Animal Ventilator, Surgivet ${ }^{\oplus}$, Smiths Medical). A multi-parameter-anaesthetic monitor (Datex Ohmeda S/5, GE) was used in all the cases to continuously monitor invasive and non-invasive arterial blood pressure, base-apex lead electrocardiogram, partial saturation of oxygen $\left(\mathrm{SpO}_{2}\right)$, end-tidal $\mathrm{CO}_{2}\left(\mathrm{EtCO}_{2}\right)$, inhaled and exhaled oxygen and isoflurane concentrations and for cases 4 and 5 spirometry pressure-volume loops. Arterial blood was sampled with a closed technique and the blood gas analysis was performed with Radiometer ABL 800 Flex, Radiometer Medical A/S, Denmark. Gas pressures were measured in $\mathrm{mmHg}$ and converted to $\mathrm{kPa}$. Infusion of balanced crystalloid solution (Ringer Lactate) was provided all over the anesthetic at 10$20 \mathrm{ml} \mathrm{kg}^{-1} \mathrm{~h}^{-1}$. Dobutamine was infused at variable dose (Table 1) targeting a mean invasive arterial pressure (MAP) of $70 \mathrm{mmHg}$.

\section{Salbutamol administration}

Salbutamol aerosol (Ventolin ${ }^{\circledR}$ nebulizer, 200 inhalations, Glaxo Smith Kline, Switzerland) as a racemic mixture was administered in all the cases for a total maximal dose of $2 \mu \mathrm{g} \mathrm{kg}^{-1}$. Salbutamol was sprayed through the same designed adapter into the Y-piece of the circle system (Figure 1) at the beginning of inspiratory phase for a number of respiratory acts equal to the number of nebulizations to be sprayed. Number of puffs to be administered was calculated for the weight of each patient. According to the manufacturer, each depression of the canister nozzle delivers $100 \mu \mathrm{g}$ of active drug.

\section{Case 1}

Twenty-five minutes after the beginning of inhalatory anesthesia, as arterial blood gas analysis revealed $\mathrm{a} \mathrm{PaO}_{2}$ of $9.41 \mathrm{kPa}(70.6 \mathrm{mmHg})\left(\mathrm{FiO}_{2}=0.92\right)$ salbutamol was administered. Mild hypercapnia $\left(\mathrm{PaCO}_{2} 6.97 \mathrm{kPa}=52.3 \mathrm{mmHg}\right)$ and lactate concentration of $2.18 \mathrm{mmol} / \mathrm{L}$ were detected at the same time. Ten minutes following the administration, HR increased from $35 \mathrm{bpm}$ to $48 \mathrm{bpm}$ and remained elevated over 5 minutes. Concomitantly, profuse sweating and a decrease in systolic blood pressure without modification of the mean arterial pressure (MAP) $(78 \mathrm{mmHg}$ ) were recorded. Heart rate (HR) returned to $34 \mathrm{bpm}$ and concomitantly blood pressure increased as well and remained stable until the end of anesthesia. $\mathrm{PaO}_{2}$ increased after salbutamol administration and fifteen minutes later was $13 \mathrm{kPa}$ (97 $\mathrm{mmHg}$ ); $\mathrm{PaCO}_{2}$ was $7.33 \mathrm{kPa}(55 \mathrm{mmHg}$ ) and lactate $2.3 \mathrm{mmol} / \mathrm{L}$. Blood gas analysis was repeated 45 minutes after salbutamol inhalation and $\mathrm{PaO} 2$ decreased again to $79 \mathrm{mmHg}$. Since the $\mathrm{PaCO}_{2}$ increased concomitantly (8.08 $\mathrm{kPa}$ ), mechanical ventilation was adapted. The horse recovered assisted uneventfully.

\section{Case 2}

Thirty minutes after the beginning of inhalatory anesthesia, as arterial blood gas analysis revealed $\mathrm{a} \mathrm{PaO}_{2}$ of $12.8 \mathrm{kPa}$ (96 mmHg) $\left(\mathrm{FiO}_{2}=0.72\right)$, salbutamol was administered. Normocapnia $\left(\mathrm{PaCO}_{2} 5.33 \mathrm{kPa}=40 \mathrm{mmHg}\right)$ and lactate concentration of $3.08 \mathrm{mmol} / \mathrm{L}$ were detected at the same time. Ten minutes following the administration, HR increased from $46 \mathrm{bpm}$ to $57 \mathrm{bpm}$ and progressively reached the peak of $72 \mathrm{bpm}$ (15 minutes later) to decrease over the following 10 minutes to $57 \mathrm{bpm}$ and stabilize around $48 \mathrm{bpm}$ subsequently. During the tachycardia phase, blood pressure did not change and remained low (MAP around $50 \mathrm{mmHg}$ ). Normal MAP could not be restored until HR decreased to the baseline, despite increasing of the dobutamine dose rate (up to a maximum of $1.5 \mu \mathrm{g} \mathrm{kg}^{-1} \mathrm{~min}^{-1}$ ) and the dose rate of fluid infusion. Concomitantly, profuse sweating was noticed. Fifteen minutes after salbutamol administration $\mathrm{PaO}_{2}$ increased to $26.67 \mathrm{kPa}(200 \mathrm{mmHg})$; $\mathrm{PaCO}_{2}$ was $5.33 \mathrm{kPa}(40 \mathrm{mmHg})$ and lactate $2.28 \mathrm{mmol} / \mathrm{L}$. Blood gas analysis was repeated 60 minutes after salbutamol administration; $\mathrm{PaO}_{2}$ was 26.13 (196 mmHg) and $\mathrm{PaCO}_{2}$ was unmodified. The horse recovered assisted uneventfully.

\section{Case 3}

Twenty minutes after the beginning of inhalatory anesthesia, the arterial blood gas analysis revealed $\mathrm{a} \mathrm{PaO}_{2}$ of $14.26 \mathrm{kPa}$ $(107 \mathrm{mmHg})\left(\mathrm{FiO}_{2}=0.6\right)$. Ten minutes later salbutamol was administered. Moderate hypercapnia $\left(\mathrm{PaCO}_{2} 8.99 \mathrm{kPa}=\right.$ $67.4 \mathrm{mmHg}$ ) and lactate concentration of $1.9 \mathrm{mmol} / \mathrm{L}$ were detected at the same time. Five minutes following the administration, HR progressively increased from $40 \mathrm{bpm}$ to $57 \mathrm{bpm}$ over 15 minutes and then decrease over the next 10 minutes to baseline. A further mild decrease to a final HR of $38 \mathrm{bpm}$ was recorded towards the end of anesthesia. During the tachycardia phase, blood pressure increased abruptly; the MAP passed from 63 to $105 \mathrm{mmHg}$, with a peak of diastolic blood pressure of $90 \mathrm{mmHg}$, followed by a progressive slow decrease to normal values. Concomitantly, the administration of dobutamine was interrupted. A new blood gas analysis conducted 20 minutes after the 


\section{Table 1 Details of anaesthetic protocol for each patient}

\begin{tabular}{|c|c|c|c|c|c|c|c|c|c|}
\hline $\begin{array}{l}\text { Case } \\
\text { details }\end{array}$ & Patient & Procedure & Premedication & Induction & Maintenance & Ventilation & $\begin{array}{l}\text { Time of } \\
\text { salbutamol } \\
\text { inhalation }\end{array}$ & Et Isoflurane\% & $\begin{array}{l}\text { Dobutamine } \\
\text { dose } \mu \mathrm{g} \mathrm{\textrm {kg } ^ { - 1 }} \mathrm{min}^{-1}\end{array}$ \\
\hline \multirow[t]{3}{*}{ Case $1 ¥$} & \multirow{3}{*}{$\begin{array}{l}14 \text { year old, } \\
\text { gelding Swiss } \\
\text { Warm Blood } \\
760 \mathrm{~kg}\end{array}$} & \multirow{3}{*}{$\begin{array}{l}\text { Emergency } \\
\text { explorative } \\
\text { laparotomy }\end{array}$} & $\begin{array}{l}\text { Romifidine } \\
40 \mathrm{\mu g} \mathrm{kg}^{-1} \mathrm{IV}\end{array}$ & $\begin{array}{l}\text { Ketamine }^{3} \\
2.2 \mathrm{mg} \mathrm{kg}^{-1} \mathrm{IV}\end{array}$ & Isoflurane in oxygen & \multirow{3}{*}{$\begin{array}{l}\text { IPPV fr }=8-10 \mathrm{~min}^{-1} \mathrm{TV}=10 \mathrm{ml} \mathrm{kg}^{-1} \\
\text { I:E ratio: } 1: 2 \text { Peak PAW }=30 \mathrm{cmH}_{2} \mathrm{O} \\
\text { PEEP }=5 \mathrm{cmH}_{2} \mathrm{O}\end{array}$} & $T_{0}=45$ & \multirow[t]{3}{*}{ Et Iso $1.1 \%$} & Minimum0.22 \\
\hline & & & \multirow{2}{*}{$\begin{array}{l}\text { Butorphanol } \\
50 \mu \mathrm{kg}^{-1} \mathrm{IV}\end{array}$} & \multirow{2}{*}{$\begin{array}{l}\text { Diazepam }{ }^{4} \\
100 \mathrm{mcg} \mathrm{kg}^{-1} \mathrm{IV}\end{array}$} & \multirow{2}{*}{$\begin{array}{l}\text { Lidocaine } 2 \%\left(30 \mu \mathrm{g} \mathrm{kg}^{-1} \mathrm{~min}^{-1}\right) \\
\text { CRI }\end{array}$} & & \multirow[t]{2}{*}{$\mathrm{T}_{1}=35$} & & Maximum 0.5 \\
\hline & & & & & & & & & $\begin{array}{l}\text { At salbutamol } \\
\text { inhalation } 0.5\end{array}$ \\
\hline \multirow[t]{4}{*}{ Case $2 ¥$} & \multirow{4}{*}{$\begin{array}{l}12 \text { year old, } \\
\text { mare Island } \\
\text { horse } 350 \mathrm{~kg}\end{array}$} & \multirow{4}{*}{$\begin{array}{l}\text { Emergency } \\
\text { explorative } \\
\text { laparotomy }\end{array}$} & $\begin{array}{l}\text { Romifidine } \mathrm{e}^{1} \\
50 \mathrm{\mu g} \mathrm{Kg}^{-1} \mathrm{IV}\end{array}$ & $\begin{array}{l}\text { Ketamine }^{3} \\
2.2 \mathrm{mg} \mathrm{Kg}^{-1} \mathrm{IV}\end{array}$ & Isoflurane in oxygen and air & \multirow[t]{4}{*}{$\begin{array}{l}\text { IPPV fr }=5 \mathrm{~min}^{-1} \mathrm{TV}=11.5 \mathrm{ml} \mathrm{kg}^{-1} \\
\text { I:E ratio: } 1: 2 \text { Peak PAW }=20 \mathrm{cmH}_{2} \mathrm{O}\end{array}$} & $T_{0}=55$ & \multirow[t]{4}{*}{ Et Iso $1 \%$} & Minimum 0.5 \\
\hline & & & \multirow{3}{*}{$\begin{array}{l}\text { Butorphanol } \\
50 \mu \mathrm{kg}^{-1} \mathrm{IV}\end{array}$} & Diazepam ${ }^{4}$ & \multirow{3}{*}{$\begin{array}{l}\text { Lidocaine } 2 \%\left(25 \mathrm{\mu g} \mathrm{kg}^{-1} \mathrm{~min}^{-1}\right) \text {, } \\
\text { ketamine }{ }^{3}\left(10 \mathrm{\mu g} \mathrm{kg}^{-1} \mathrm{~min}^{-1}\right) \text { and } \\
\text { guafenesin }{ }^{5}\left(0.4 \mathrm{mg}^{-1} \mathrm{~kg}^{-1} \min ^{-1}\right) \text { CRI }\end{array}$} & & \multirow[t]{3}{*}{$\mathrm{T}_{1}=40$} & & Maximum 1.5 \\
\hline & & & & $50 \mathrm{mcg} \mathrm{kg}$ iV & & & & & At salbutamol \\
\hline & & & & $\begin{array}{l}\text { Guaifenesine to } \\
\text { effect IV }\end{array}$ & & & & & inhalation 0.75 \\
\hline \multirow[t]{3}{*}{ Case $3^{*}$} & \multirow{3}{*}{$\begin{array}{l}6 \text { month old, } \\
\text { male Swiss } \\
\text { warm blood } \\
265 \mathrm{~kg}\end{array}$} & \multirow{3}{*}{$\begin{array}{l}\text { Elective scrotal } \\
\text { herniorraphy } \\
\text { and castration }\end{array}$} & $\begin{array}{l}\text { Acepromazine } \\
30 \mu \mathrm{Kg}^{-1} \mathrm{IM}\end{array}$ & $\begin{array}{l}\text { Ketamine }^{3} \\
2.2 \mathrm{mg} \mathrm{Kg}^{-1} \mathrm{IV}\end{array}$ & Isoflurane in oxygen & \multirow{3}{*}{$\begin{array}{l}\text { Spontaneous breathing IPPV (after } \\
\text { salbutamol administration) fr }=6 \mathrm{~min}^{-1} \\
\text { TV }=15 \mathrm{ml} \mathrm{kg}^{-1} \text { l:E ratio: } 1: 2 \text { Peak } \\
\text { PAW }=25 \mathrm{cmH}_{2} \mathrm{O}\end{array}$} & $\mathrm{T}_{1}=45$ & \multirow[t]{3}{*}{ Et Iso $1.1 \%$} & Minimum 0.6 \\
\hline & & & $\begin{array}{l}\text { Romifidine } \\
50 \mathrm{\mu g} \mathrm{Kg}^{-1} \mathrm{IV}\end{array}$ & $\begin{array}{l}\text { Diazepam }{ }^{4} \\
100 \mathrm{mcg} \mathrm{kg}^{-1} \mathrm{IV}\end{array}$ & \multirow[t]{2}{*}{ Romifidine $\left(0.6 \mu \mathrm{g} \mathrm{kg}^{-1} \mathrm{~min}^{-1}\right) \mathrm{CRI}$} & & $\mathrm{T}_{0}=55$ & & Maximum 1.6 \\
\hline & & & $\begin{array}{l}\text { L- Methadone } \\
50 \mu \mathrm{Kg}^{-1} \mathrm{IV}\end{array}$ & $\begin{array}{l}\text { Guaifenesine } \\
\text { to effect IV }\end{array}$ & & & & & $\begin{array}{l}\text { At salbutamol } \\
\text { inhalation } 0.6\end{array}$ \\
\hline \multirow[t]{3}{*}{ Case $4^{*}$} & \multirow{3}{*}{$\begin{array}{l}4 \text { month old, } \\
\text { male Polo } \\
\text { Pony } 200 \mathrm{~kg}\end{array}$} & \multirow{3}{*}{$\begin{array}{l}\text { Elective } \\
\text { humbelical } \\
\text { herniorraphy }\end{array}$} & $\begin{array}{l}\text { Acepromazine } \\
30 \mathrm{\mu g} \mathrm{kg}^{-1} \mathrm{IM}\end{array}$ & $\begin{array}{l}\text { Ketamine }^{3} \\
2.2 \mathrm{mg} \mathrm{kg}^{-1} \mathrm{IV}\end{array}$ & \multirow[t]{3}{*}{ Isoflurane in oxygen and air } & \multirow{3}{*}{$\begin{array}{l}\text { Spontaneous breathing; IPPV (before } \\
\text { salbutamol administration) TV }=2200 \mathrm{ml} \\
\mathrm{fr}=7 \mathrm{~min}^{-1} \mathrm{TV}=13 \mathrm{ml} \mathrm{kg} \mathrm{kg}^{-1}(2550 \mathrm{ml}) \\
\text { I:E ratio: } 1: 2 \text { Peak PAW }=30 \mathrm{cmH}_{2} \mathrm{O}\end{array}$} & $\mathrm{T}_{0}=35$ & \multirow[t]{3}{*}{ Et Iso $1.3 \%$} & Minimum 0.8 \\
\hline & & & $\begin{array}{l}\text { Romifidine }^{1} \\
60 \mathrm{\mu g} \mathrm{kg}^{-1}\end{array}$ & $\begin{array}{l}\text { Diazepam }{ }^{4} \\
100 \mathrm{mcg} \mathrm{kg}^{-1} \mathrm{IV}\end{array}$ & & & $\mathrm{T}_{1}=28$ & & Maximum 1.6 \\
\hline & & & $\begin{array}{l}\text { Butorphanol } \\
40 \mathrm{\mu g} \mathrm{kg}^{-1}\end{array}$ & & & & & & $\begin{array}{l}\text { At salbutamol } \\
\text { inhalation } 1.6\end{array}$ \\
\hline \multirow[t]{3}{*}{ Case $5+$} & \multirow{3}{*}{$\begin{array}{l}10 \text { year old, } \\
\text { gelding male } \\
\text { Swiss warm } \\
\text { blood } 670 \mathrm{~kg}\end{array}$} & \multirow{3}{*}{$\begin{array}{l}\text { Emergency } \\
\text { carpus } \\
\text { arthroscopy }\end{array}$} & $\begin{array}{l}\text { Romifidine } \\
60 \mathrm{\mu g} \mathrm{kg}^{-1} \mathrm{IV}\end{array}$ & $\begin{array}{l}\text { Ketamine }^{3} \\
2.2 \mathrm{mg} \mathrm{Kg}^{-1} \mathrm{IV}\end{array}$ & Isoflurane in oxygen and air & \multirow[t]{3}{*}{ Spontaneous breathing TV $=5600 \mathrm{ml}$} & $\mathrm{T}_{0}=85$ & \multirow[t]{3}{*}{ Et Iso $1.1 \%$} & Minimum 0.12 \\
\hline & & & \multirow{2}{*}{$\begin{array}{l}\text { L- Methadone } \\
50 \mu \mathrm{kg}^{-1} \mathrm{IV}\end{array}$} & \multirow{2}{*}{$\begin{array}{l}\text { Diazepam }{ }^{4} \\
100 \mathrm{mcg} \mathrm{kg}^{-1} \mathrm{IV}\end{array}$} & Romifidine $\left(0.6 \mu \mathrm{g} \mathrm{kg}^{-1} \mathrm{~min}^{-1}\right) \mathrm{CRl}$ & & $\mathrm{T}_{1}=70$ & & Maximum 0.5 \\
\hline & & & & & & & & & $\begin{array}{l}\text { At salbutamol } \\
\text { inhalation } 0.12\end{array}$ \\
\hline
\end{tabular}

*This patient was ventilated after hypoxia and hypercapnia were detected; $¥$ these patients underwent mechanical ventilation from the beginning of inhalational anesthesia; this patient was allowed to breath

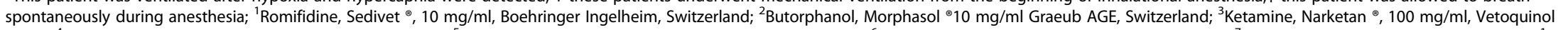

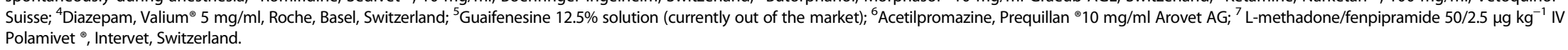

$T O=$ Time between romifidine injection at the sedation and salbutamol inhalation. $T 1=$ Time between ketamine injection at the injection and salbutamol inhalation expressed in minutes 


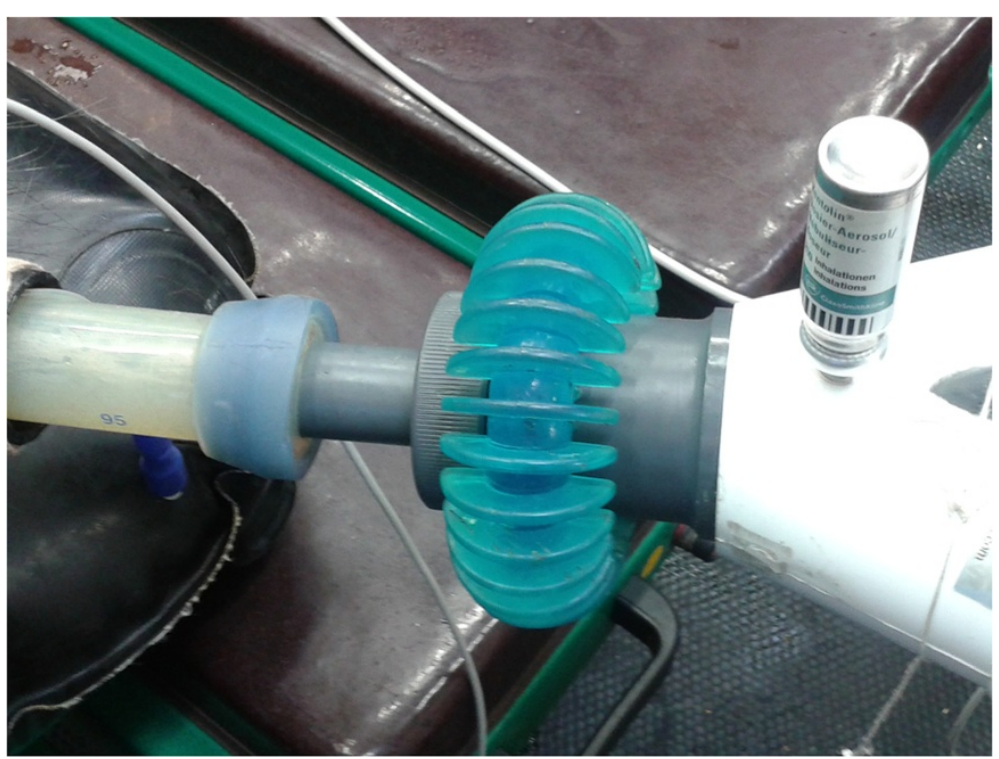

Figure 1 Inhalation of salbutamol. Salbutamol spray canister inserted into the adapter of the $Y$ connection of the circle system during general anesthesia.

salbutamol administration revealed no improvement of $\mathrm{PaO}_{2}(14.26 \mathrm{kPa}=107 \mathrm{mmHg})$ and moderate hypercapnia was confirmed, therefore mechanical ventilation was started. The horse recovered assisted uneventfully.

\section{Case 4}

Fifteen minutes after the beginning of inhalatory anesthesia, as arterial blood gas analysis revealed a $\mathrm{PaCO}_{2}$ of $10.04 \mathrm{kPa}$ $(75.3 \mathrm{mmHg})$ and $\mathrm{a} \mathrm{PaO}_{2}$ of $9.34 \mathrm{kPa}(70.5 \mathrm{mmHg})$ $\left(\mathrm{FiO}_{2}=0.58\right)$, salbutamol was administered. A lactate concentration of $2.1 \mathrm{mmol} / \mathrm{L}$ was detected at the same time. Concomitantly IPPV was started. Measured tidal volume was $3.2 \mathrm{~L}$. Spirometric volume- pressure loops indicated reduced compliance. Ten minutes after salbutamol administration, HR progressively increased from $42 \mathrm{bpm}$ to $69 \mathrm{bpm}$ and 15 minutes later reached the peak of $72 \mathrm{bpm}$ to progressively decrease over the following 30 minutes to $57 \mathrm{bpm}$. A moderate decrease in the blood pressure was noticed after salbutamol administration and dobutamine was continuously administered over the entire procedure to maintain the MAP in the range of 69 to $72 \mathrm{mmHg}$. A new blood gas analysis conducted 30 minutes after salbutamol administration and beginning of IPPV revealed a clear improvement of $\mathrm{PaO}_{2}(37.9 \mathrm{kPa}=284 \mathrm{mmHg}) ; \mathrm{PaCO}_{2}=7.28 \mathrm{kPa}$ and lactate $2.1 \mathrm{mmol} / \mathrm{L}$. The horse recovered assisted uneventfully.

\section{Case 5}

Fifteen minutes after the beginning of inhalatory anesthesia, arterial blood gas analysis revealed a $\mathrm{PaCO}_{2}$ of $7.04 \mathrm{kPa}$

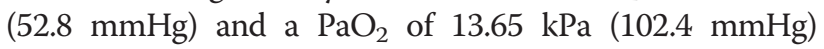

$\left(\mathrm{FiO}_{2}=0.65\right)$. A second blood gas analysis was conducted 45 minutes later and revealed a $\mathrm{PaCO}_{2}$ of $7.49 \mathrm{kPa}$ (56.2 $\mathrm{mmHg}$ ) and $\mathrm{PaO}_{2}$ of $10.18 \mathrm{kPa}(76.4 \mathrm{mmHg})$ $\left(\mathrm{FiO}_{2}=0.87\right)$. At this time point, salbutamol was administered. Five minutes after salbutamol administration, a profuse sweating started and HR progressively increased from $30 \mathrm{bpm}$ to $46 \mathrm{bpm}$ and in the following 15 minutes increased abruptly to $80 \mathrm{bpm}$ and over ten further minutes reached the peak of $100 \mathrm{bpm}$. A run of premature ventricular complexes appeared on the sinus rhythm, followed by some regular sinus complexes, and immediately after ventricular tachycardia succeeded (recorded HR was between 95 and $100 \mathrm{bpm}$ ). Parallel with the development of tachycardia, the mean blood pressure decreased sharply from 80 to a minimum of $45 \mathrm{mmHg}$ (Figure 2). Dobutamine CRI was stopped and a bolus of colloids of $2 \mathrm{ml} \mathrm{kg}^{-1} \mathrm{~h}^{-1}$ (Voluven ${ }^{\circ} 6 \%$ balanced, Fresenius Kabi, $\mathrm{CH}$ ) was administered over $10 \mathrm{mi}-$ nutes. A bolus of $1.5 \mathrm{mg} \mathrm{kg}^{-1}$ lidocaine was administered over 5 minutes. Continuous rate infusion of phenylephrine was started at $0.01 \mu \mathrm{g} \mathrm{kg}^{-1} \mathrm{~min}^{-1}$ and then stopped when the MAP reached a value above $60 \mathrm{mmHg}$. Consequently, the HR decreased slowly and progressively and synusal rhythm reappeared. A new blood gas analysis conducted 20 minutes after salbutamol administration at $\mathrm{FiO}_{2}$ of 0.8 revealed ameliorated $\mathrm{PaO}_{2}(21.2 \mathrm{kPa}=159 \mathrm{mmHg})$ and moderate hypercapnia $\left(\mathrm{PaCO}_{2}=8.44 \mathrm{kPa}=63.3 \mathrm{mmHg}\right)$. Lactate plasma level $(1.0 \mathrm{mmol} / \mathrm{L})$ did not increase. After the end of the surgical procedure, which terminated $50 \mathrm{mi}-$ nutes after salbutamol administration, the horse was transferred to the recovery stall under ECG monitoring. Blood gas analysis at the end of the surgery was unvaried: 


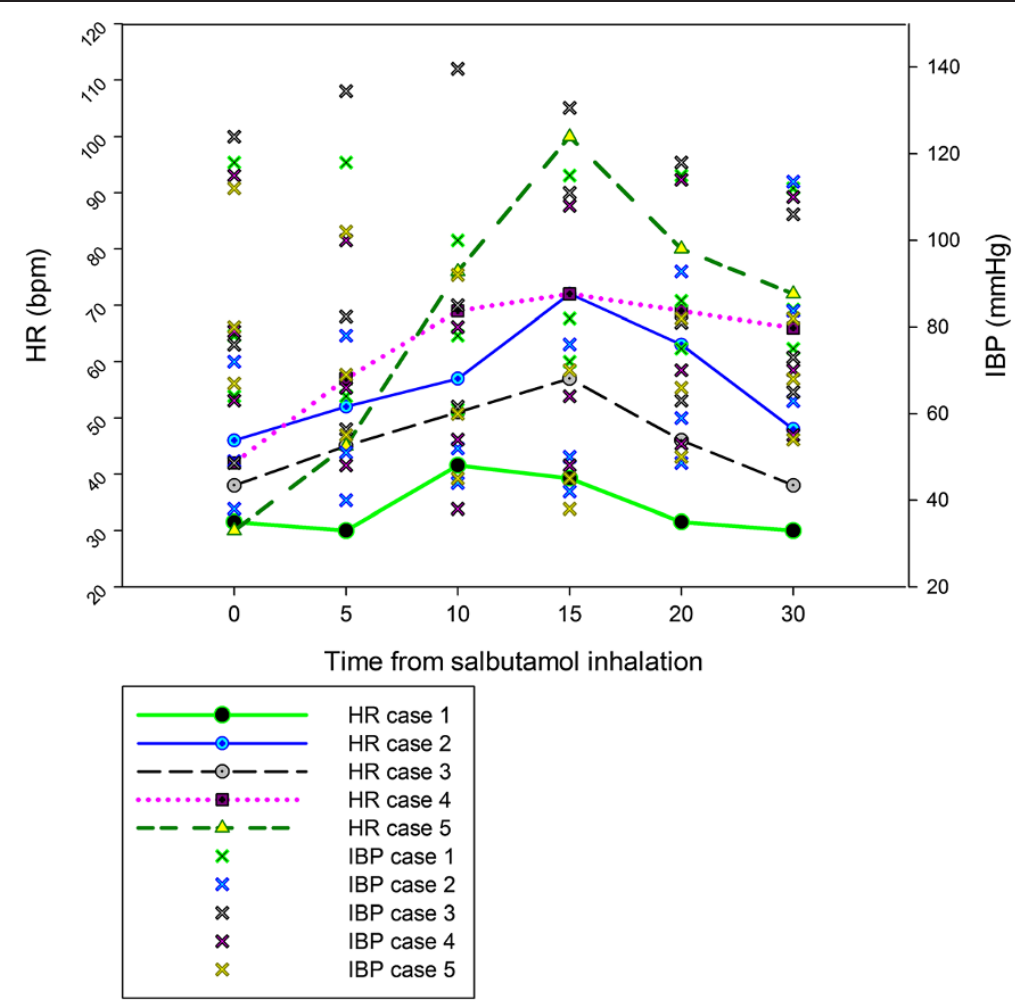

Figure 2 Cardiovascular effect of salbutamol inhalation. $\mathrm{HR}=$ heart rate (along the left y axis) and IBP = invasive blood pressure (along the right $y$ axis) variations after salbutamol inhalation. On the $x$ axis time 0 represents salbutamol inhalation. Systolic, mean and diastolic blood pressures are represented.

$\mathrm{PaO}_{2}$ was $23 \mathrm{kPa}(172.5 \mathrm{mmHg}), \mathrm{PaCO}_{2} 8 \mathrm{kPa}(60 \mathrm{mmHg})$ and lactate plasma level $1.1 \mathrm{mmol} / \mathrm{L}$. The trend of progressive, slow decrease of HR was confirmed and when the horse showed the first sign of nystagmus, romifidine at $10 \mu \mathrm{g} \mathrm{kg}^{-1}$ was administered as post-operative sedation and the ECG monitoring interrupted. The horse recovered assisted uneventfully.

\section{Conclusions}

This case series describes the occurrence of adverse cardiovascular effects in 5 horses associated with the inhalation of salbutamol at clinical advised doses during general anesthesia. The treatment of suboptimal oxygen arterial pressure in horses has proven to be difficult and no efficacious therapy to counteract it has been established yet. The authors utilize in their daily practice inhalational salbutamol as treatment of hypoxemia taking advantage of the ease and the non-invasiveness of the technique. However, the occurrence of a cardiovascular impairment in the five cases described above warns against potential detrimental effects of the $\beta-2$ agonist inhalation. To the best of the authors' knowledge there are no previous reports in literature describing the appearance of cardiovascular adverse effects after salbutamol administration in a clinical setting. In 4 out of 5 horses, the cardiovascular impairment could be corrected by adjusting the supportive therapy already administered during the anesthesia. However, in one horse (case 5) the occurrence of ventricular tachycardia and the severe decreasing of the blood pressure required additional therapy. As the peripheral vasodilation was a major concern and as the surgical operation was almost completed, the hypotension was treated with phenylephrine in light of its prevalent action as vasoconstrictor acting on post-synaptic $\alpha-1$ receptors. In none of the cases was cardiac output measured before or after the salbutamol administration, therefore variations in blood pressure and heart rhythm were the only objective indicators of cardiovascular derangement. In light of the strong temporal association between the administration of salbutamol and the recorded cardiovascular impairment, the authors consider the inhalation of salbutamol its most likely cause. In none of the cases, was the sudden tachycardia either associated with surgical incision or further painful stimulation and supportive measures to restore the cardiovascular stability were successful. Hypovolemia was unlikely the case of the cardiovascular modification in case 1 as the observed tachycardia was of short duration and associated with sweating. In case 2 , despite the suboptimal blood pressure recorded at the 
beginning of anesthesia could have been indicative of a fluid deficit, hypovolemia cannot explain the sudden tachycardia and the profuse sweating after inhalation of salbutamol. In case 5 no arrhythmias were detected prior or after the anaesthetic and no abnormalities were recorded on the ECG once the horse recovered, therefore a pre-existing cardiac disease seems to be unlikely in this horse. Investigating the clinical impact of such cardiac impairment on a longer term is difficult; variations of lactate serum levels after salbutamol administration could be indicative of impaired peripheral perfusion. The arterial lactate measured after salbutamol administration was not increased in our cases, however all the horses underwent supportive therapy which could have prevented the reduction of peripheral perfusion.

Cardiovascular impairment following inhalation of salbutamol is probably owing to systemic uptake.

In our cases, two anesthetists (DC and CA) used the same technique to spray salbutamol into the trachea as previously described. This technique has been described by Robertson and Bailey [1] in clinical horses lying in dorsal recumbency and utilized by Patschova et al. [11] in experimental horses.

In our cases, the total number of nebulizations to be administered was calculated on the base of measured weight. Therefore is improbable that an absolute overdosage due to any procedural change could be the cause of the observed adverse effects. However, different filling of the canister, different humidity degree of the inner part of the inspiratory limb and endotracheal tube and slightly different delivered flow of the carrier gases cannot be ruled out as factors influencing the actual dose of drug delivered. Whether these potential differences in the actual dose could have influenced the percentage of systemic absorption is difficult to evaluate. More importantly, we did not deliver salbutamol through the MDI adapter (PriMed Co, Largo, Florida, USA) that the previous authors $[1,8]$ utilized. This adapter is specifically designed to allow salbutamol entering the midstream of gas flow and carrying it far down the bronchial tree allowing its binding to the target sites; thus, in our case, salbutamol could have precipitated earlier, leading to partial absorption into the systemic blood stream from the trachea. If so, a better standardization of the delivery technique has to be taken into higher consideration and alternative administration techniques [12] only consciously advised.

Independently of the adapter, the hypothesis of a clinical relevant systemic uptake of the drug was already formulated by Robertson and Bailey, as they noticed an excessive sweating in some horses, but not accompanied by an increase in heart rate. Inhaled $\beta_{2}$ adrenoreceptor agonists, to which salbutamol belongs, are the most effective known bronchodilators. It has been demonstrated that inhaled salbutamol induces acute cardiac electrophysiologic effects in humans, especially tachycardia and shortened node recovery time [13]. In human medicine there is a body of evidence that $\beta_{2}$ receptors are not only represented into the tracheal and bronchial musculature, but also in the atrium and ventricular myocardium and play a significant role in physiologic and pathologic conditions $[14,15]$. It is well known that the equine tracheal musculature expresses predominantly $\beta_{2}$ receptors [16]; however contrasting results are reported concerning their concentration in the heart. Indeed, Törneke [17] found a small proportion of $\beta_{2}$ adrenoreceptors in the normal equine ventricular myocardium, while Horn et al. [18] could not demonstrate the presence of $\beta_{2}$ adrenoreceptors in normal equine myocardium, and concluded that their density increases only during heart failure. According to the same authors, this discrepancy between studies could be attributed to differences among individual horses or between sites of ventricular muscle sampled. It is also difficult to find evidence whether the prevalent selectivity towards $\beta_{2}$ receptors reported for salbutamol is relevant "in vivo". It can be hypothesized that in some horses salbutamol could have acted as $\beta_{1}$ agonist as well. Therefore, the systemically absorbed salbutamol could have caused the chronotropic effects via $\beta_{1}$ adrenoreceptor activity, which are anyhow the prevalent population in the equine heart. Alternatively, one could speculate that horses with greater population of $\beta_{2}$ receptors could be more sensitive to the action of salbutamol than horses with a smaller population.

Differently from what could be expected, the blood pressure trend recorded concomitantly to the rhythm modification in our 5 cases was inconsistent. Although the specific mechanisms that control vascular tone are not completely understood, it has been shown in rats that increasing density of $\beta_{2}$ receptors in the vascular walls enhances vasorelaxation [19]. Different anaesthetic protocols were used in the described cases. However, in all cases, romifidine was administered as premedication and in case 3 and 5 additionally as CRI, salbutamol being administered relatively early after the beginning of inhalation anesthesia. Romifidine infused at the dose of $40 \mu \mathrm{g} \mathrm{kg}^{-1} \mathrm{~h}^{-1}$ has been reported not having influence on the blood pressure in isoflurane anaesthetized horses premedicated with romifidine at a standard dose of $80 \mu \mathrm{g} \mathrm{kg}^{-1}$ [20]. However, it cannot be excluded that the hypotension observed in the case 1 and 4 was brought about by the activation of the vascular $\beta_{2}$ receptors, which overcame the increased vascular resistance mediated by the action of romifidine administered in premedication on the $\alpha_{1}$ receptors. A decrease in stroke volume owing to an excessive reduction of diastolic time should also be taken into account, especially in case 4, in which the tachycardia was major. In case 5, lidocaine 
and phenylephrine were efficacious in restoring blood pressure and normal cardiac rhythm: abnormal ventricular contraction or massive vascular relaxation can both be claimed as responsible of the symptoms. Whether it was the normalized cardiac contractility or the improved vascular tone, the main contributor to the clinical amelioration cannot be differentiated.

In two cases (case 3 and case 5) the patients received salbutamol while they were breathing spontaneously. The decision to administer inhalational salbutamol as a corrective measure of inadequate $\mathrm{PaO}_{2}$ instead of starting IPPV was based on the values of $\mathrm{PaCO}_{2}$ measured in the blood. In the cases of normocapnia or slight hypercapnia $\left(\mathrm{PaCO}_{2}\right.$ up to $\left.55 \mathrm{mmHg}\right)$ the preference of the authors was to allow the patients to breath spontaneously. Although the difference between the amount of drug delivered through a negative and a positive pressure driven inspiratory phase has never been tested, it is unlikely that a lower tidal volume can be correlated with a higher percentage of inspired salbutamol after a nonpreset inspiratory act. In case 3, the spirometry was not included in the monitoring, but in case 5 a tidal volume of $5.6 \mathrm{~L}$ was recorded from the Pitot tube and this volume is lower than the volume one would have set in a regimen of mechanical ventilation. Therefore it is unlikely that the spontaneous breathing could have been the cause of increased inspired salbutamol. However it is worth mentioning that the inhalation of salbutamol has been previously described in horses under controlled ventilation, which implies a different respiratory mechanics from spontaneous breathing. When considering either the efficacy of the technique or the collateral effects observed, this variable has also to be taken into account.

It is also difficult to define which cut-off of $\mathrm{PaO}_{2}$ should be chosen to plan a salbutamol treatment. In fact, due to the great affinity of equine hemoglobin for oxygen, absolute hypoxemia is arbitrarily defined as a $\mathrm{PaO}_{2}$ lower than $60 \mathrm{mmHg}[12,21]$. However, suboptimal $\mathrm{PaO}_{2}$ reflecting an inadequacy of ventilation can be identified in horses during general anesthesia and still represents a therapeutic challenge. $\mathrm{PaO}_{2}$ might even not improve, as observed in case 3 , if inhalation of salbutamol is provided at higher $\mathrm{PaO}_{2}$ without addressing other potential causes of hypoxia. Furthermore, if the improvement of the $\mathrm{PaO}_{2}$ is not followed by an increase in the oxygen delivery, due to harmful cardiovascular alterations, the therapeutic intervention may be useless or even harmful. Since the consequences of relative and absolute hypoxia in equine anesthesia are still not completely understood, and seem not be major [22], in the light of the potential complications observed, it is probably worth limiting the use of salbutamol to the cases of true hypoxia non-responsive to mechanical ventilation.
In conclusion, taking into account that significant cardiovascular effects of inhaled salbutamol can occur in horses as reported in humans, the use of inhaled salbutamol should not be considered completely harmless and its use has to be pondered. Other therapeutic options to improve oxygenation should be considered in spontaneous breathing horses. If the case, supportive therapy is required and crystalloids, dobutamine, phenylephrine and lidocaine can be administered for the treatments of salbutamol side effects. No further adverse consequences were either recorded until the end of general anesthesia or during the recovery phase.

\section{Consent}

Written informed consent was obtained from the patients' owners for the publication of this report and any accompanying images.

\section{Competing interests}

The authors declare that they have no competing interests.

\section{Authors' contributions}

DC and CA carried the anesthesias out and were responsible of perioperative care in the five cases. They contributed at the same extent to the preparation of the manuscript. CS supervised the anesthetics and gave valuable input to the final manuscript. All authors read and approved the final manuscript.

Received: 14 March 2014 Accepted: 7 August 2014

Published: 14 August 2014

\section{References}

1. Robertson SA, Bailey JE: Aerosolized salbutamol (albuterol) improves $\mathrm{PaO}_{2}$ in hypoxaemic anaesthetized horses-a prospective clinical trial in 81 horses. Vet Anaesth Analg 2002, 29:212-218.

2. Nyman G, Funkquist B, Kvart C: Postural effects on blood gas tension, blood pressure, heart rate, ECG and respiratory rate during prolonged anesthesia in the horse. Zentralb/ Veterinarmed A 1988, 35:54-62.

3. Nyman G, Hedenstierna $G$ : Ventilation-perfusion relationships in the anaesthetised horse. Equine Vet J 1989, 21:274-281.

4. Whitehair KJ, Willits NH: Predictors of arterial oxygen tension in anesthetized horses: 1,610 cases (1992-1994). J Am Vet Med Assoc 1999, 215:978-981.

5. Nyman G, Funkquist B, Kvart C, Frostell C, Tokics L, Strandberg A, Lundquist H, Lundh B, Brismar B, Hedenstierna G: Atelectasis causes gas exchange impairment in the anaesthetised horse. Equine Vet J 1990, 22:317-324.

6. Dodam JR, Moon RE, Olson NC, Exposito AJ, Fawcett TA, Huang YC, Theil DR, Camporesi E, Swanson CR: Effects of clenbuterol hydrochloride on pulmonary gas exchange and hemodynamics in anesthetized horses. Am J Vet Res 1993, 54:776-782.

7. Lee $\mathrm{YH}$, Clarke KW, Alibhai HI: The cardiopulmonary effects of clenbuterol when administered to dorsally recumbent halothane-anaesthetised ponies failure to increase arterial oxygenation. Res Vet Sci 1998, 65:227-232.

8. Baker JG: The selectivity of beta-adrenoceptor agonists at human $\beta_{1^{-}}, \beta_{2^{-}}$ and $\beta_{3}$-adrenoceptors. Br J Pharmacol 2010, 160:1048-1061.

9. Spiekerkoetter E, Fabel H, Hoeper MM: Effects of inhaled salbutamol in primary pulmonary hypertension. Eur Resp J 2002, 20:524-528.

10. Derksen FJ, Olszewski MA, Robinson NE, Berney C, Hakala JE, Matson CJ, Ruth DT: Aerosolized albuterol sulfate used as a bronchodilator in horses with recurrent airway obstruction. Am J Vet Res 1999, 60:689-693.

11. Patschova M, Kabes $R$, Krisova S: The effects of inhalation salbutamol administration on systemic and pulmonary hemodynamic, pulmonary mechanics and oxygen balance during general anesthesia in the horse. vet Med (Praha) 2010, 55:445-456. 
12. Palos H-M: Hypoxemia and hypoxia. In Manual of Equine Anesthesia and Analgesia. Edited by Doherty T, Valverde A. Blackwell Publishing Ltd; 2006:313. 2006.

13. Kallergis EM, Manios EG, Kanoupakis EM, Schiza SE, Mavrakis HE, Klapsinos NK, Vardas PE: Acute electrophysiologic effects of inhaled salbutamol in humans. Chest 2005, 126:2057-2063.

14. Brodde OE: Beta 1- and beta 2-adrenoceptors in the human heart: properties, function, and alterations in chronic heart failure. Pharmacol Rev 1991, 43:203-242.

15. Bristow MR, Ginsburg R: Beta 2 receptors on myocardial cells in human ventricular myocardium. Am J Cardiol 1986, 57:3F-6F.

16. Toerneke K, Larsson Cl, Appelgren LE: Relaxation of equine tracheal muscle in vitro by different adrenoceptor drugs. I Vet Pharmacol Ther 1997, 20:216-219.

17. Toerneke K: Beta-adrenoreceptors in equine trachea and heart. Vet Res Commun 1999, 23:41-51

18. Horn J, Bailey S, Berhane Y, Marr CM, Elliott J: Density and binding characteristics of beta-adrenoceptors in the normal and failing equine myocardium. Equine Vet J 2002, 34:411-416.

19. Gaballa MA, Peppel K, Lefkowitz RJ, Aguirre M, Dolber PC, Pennock GD, Koch WJ, Goldman S: Enhanced vasorelaxation by overexpression of beta 2-adrenergic receptors in large arteries. J Mol Cell Cardiol 1998, 30:1037-1045.

20. Devisscher L, Schauvliege S, Dewulf J, Gasthuys F: Romifidine as a constant rate infusion in isoflurane anaesthetized horses: a clinical study. Vet Anaesth Analg 2010, 37:425-433.

21. Wagner AE: Complications in Equine Anaesthesia. Vet Clin North Am Equine Pract 2009, 24:735-752.

22. Whitehair KJ, Steffey EP, Woliner MJ, Willits NH: Effects of inhalation anesthetic agents on response of horses to three hours of hypoxemia. Am J Vet Res 1996, 57:351-360.

doi:10.1186/s13028-014-0049-z

Cite this article as: Casoni et al: Cardiovascular changes after administration of aerosolized salbutamol in horses: five cases. Acto Veterinaria Scandinavica 2014 56:49.

\section{Submit your next manuscript to BioMed Central and take full advantage of:}

- Convenient online submission

- Thorough peer review

- No space constraints or color figure charges

- Immediate publication on acceptance

- Inclusion in PubMed, CAS, Scopus and Google Scholar

- Research which is freely available for redistribution 